\title{
PENERAPAN E-LEARNING DENGAN MEDIA SCHOOLOGY UNTUK MENINGKATKAN MOTIVASI DAN HASIL BELAJAR SISWA PADA KOMPETENSI DASAR MENDESKRIPSIKAN KONSEP BADAN USAHA DALAM PEREKONOMIAN INDONESIA
}

\author{
Nur Laila Ulva ${ }^{1}$, Sri Kantun ${ }^{1}$, Joko Widodo ${ }^{1}$ \\ ${ }^{1}$ Program Studi Pendidikan, Fakultas Keguruan dan Ilmu Pendidikan, Universitas Jember \\ e-mail: srikantunilyas@ymail.com
}

\begin{abstract}
Abstrak
Penelitian ini bertujuan untuk: 1) mendeskripsikan penerapan E-Learning dengan media Schoology dalam meningkatkan motivasi dan hasil belajar siswa pada Kompetensi Dasar Konsep Badan Usaha dalam Perekonomian Indonesia kelas X SOS 1 SMAN 4 Jember semester genap tahun ajaran 2016/2017, 2) untuk meningkatkan motivasi dan hasil belajar siswa melalui penerapan E-Learning dengan media Schoology pada Kompetensi Dasar Konsep Badan Usaha dalam Perekonomian Indonesia kelas X SOS 1 SMAN 4 Jember semester genap tahun ajaran 2016/2017. Penelitian ini merupakan penelitian tindakan kelas (PTK) yang terdiri atas dua siklus. Setiap siklus terdiri atas tahap perencanaan, pelaksanaan tindakan, pengamatan (observasi) dan refleksi. Subyek penelitian ini adalah seluruh siswa kelas X SOS 1 SMAN 4 Jember yang berjumlah 36 siswa. Teknik pengumpulan data meliputi observasi, wawancara, tes, dan dokumen. Teknik analisis data menggunakan analisis data deskriptif kualitatif. Hasil penelitian menunjukkan bahwa: Motivasi belajar siswa pada siklus I sebesar 2,7 dengan kriteria sedang, meningkat menjadi 3,5 dengan kriteria tinggi pada siklus II. Sedangkan rata-rata nilai hasil belajar siswa pada siklus I sebesar 78,19 dengan ketuntasan klasikal sebesar 75\%, meningkatkan menjadi 86,19 dengan ketuntasan klasikal 83,33\% pada siklus II. Kesimpulan dari penelitian ini adalah penerapan e-learning dengan media Schoology dapat meningkatkan motivasi dan hasil belajar siswa kelas X SOS 1 SMAN 4 Jember pada kompetensi dasar mendeskripsikan konsep badan usaha dalam perekonomian Indonesia semester genap tahun ajaran 2016/2017.
\end{abstract}

Kata Kunci: Motivasi belajar siswa, hasil belajar siswa, media schoology

\section{PENDAHULUAN}

Keberhasilan pembelajaran dalam penerapan kurikulum 2013 perlu ditunjang dengan penggunaan Teknologi Informasi dan Komunikasi (TIK) sebagai media pembelajaran untuk menyampaikan materi pelajaran agar lebih mudah dipahami oleh siswa. Kemajuan TIK dalam penerapan kurikulum 2013 telah menciptakan pembelajaran berbasis internet atau online yang sering disebut dengan Electronic Learning (E-Learning). Sanaky (2013:239) menjelaskan bahwa E-learning merupakan proses pembelajaran yang difasilitasi dan didukung melalui pemanfaatan teknologi informasi dan internet. Pengintegrasian TIK dalam kegiatan pembelajaran pada Kurikulum 2013 ini berlaku untuk semua mata pelajaran, salah satunya adalah mata pelajaran ekonomi di tingkat Sekolah Menengah Atas (SMA).

Mata pelajaran ekonomi kompetensi dasar konsep badan usaha dalam perekonomian Indonesia merupakan salah satu materi pembelajaran yang membahas konsep-konsep teori yang berkaitan dengan kehidupan masyarakat sehari-hari. Oleh karena itu guru harus mampu menyajikan materi yang dapat menarik perhatian siswa serta menghadirkan permasalahan-permasalahan atau perkembangan badan usaha dalam perekonomian Indonesia baik dalam bentuk tabel, gambar, maupun video dalam kegiatan pembelajaran sehingga materi akan lebih mudah dipahami oleh siswa.

Pengintegrasian TIK dalam kegiatan pembelajaran ekonomi di SMA Negeri 4 Jember sampai saat ini masih terbatas pada penggunaan Komputer dan LCD Proyektor sebagai media presentasi guru dan siswa dengan media power point yang disampaikan dengan sistem pembelajaran konvensional. 
Berdasarkan wawancara awal dengan guru mata pelajaran ekonomi kelas X SOS 1 menyatakan bahwa penggunaan media powerpoint dalam pembelajaran ekonomi ternyata belum memberikan dampak positif pada tingkat motivasi belajar siswa. Hal tersebut ditunjukkan dengan ketika proses pembelajaran berlangsung terlihat semangat belajar dan minat siswa terhadap pembelajaran masih rendah seperti siswa yang masih lebih banyak pasif, siswa kurang memperhatikan penjelasan guru dan siswa cepat bosan dengan pembelajaran dikelas karena media yang digunakan guru kurang menarik dan masih banyak siswa yang tidak tepat waktu dalam mengumpulkan tugas.

Motivasi belajar siswa yang rendah berdampak pada hasil belajar yang diperoleh siswa. Berdasarkan dokumen yang diperoleh dari guru ekonomi menunjukkan bahwa hasil belajar siswa kelas $\mathrm{X}$ SOS 1 SMAN 4 Jember masih rendah yaitu nilai rata-rata hasil belajar yang diperoleh siswa pada KD sebelumnya sebesar 69,5 dengan ketuntasan klasikal 52,77\% dan dinyatakan belum tuntas kerena nilai rata-ratanya masih dibawah KKM yang ditentukan sekolah yaitu $\geq 78$ dengan ketuntasan klasikal minimal $75 \%$.

Media yang selama ini digunakan guru perlu diperbaiki untuk mengatasi permasalahan diatas. Salah satu media yang sesuai untuk digunakan adalah media Schoology yang disajikan dalam bentuk pembelajaran berbasis internet atau yang seirng disebut dengan e-learning. Aminoto dan Pathoni (2014) menyatakan bahwa Schoology merupakan salah satu laman web yang berbentuk web sosial yang menawarkan pembelajaran sama seperti di dalam kelas secara gratis dan mudah digunakan seperti facebook. Media Schoology memungkinkan guru untuk melakukan kegiatan belajar mengajar dengan siswa di luar kelas seperti mengadakan dan memantau jalannya diskusi melalui media Schoology dan siswa dapat berperan secara langsung didalamnya. Kelebihan media Schoology adalah didukung oleh berbagai bentuk media seperti video, audio, dan gambar yang dapat menarik perhatian siswa terhadap kegiatan pembelajaran. Schoology juga memiliki fitur yang sangat lengkap dengan berbagai alat pembelajaran sama seperti dikelas seperti absensi, tes dan kuis, dan kotak untuk mengumpulkan tugas atau pekerjaan rumah. Schoology mengarahkan siswa mengaplikasikan penggunaan teknologi dalam pembelajaran.

Penelitian sejenis sudah pernah dilakukan oleh Pertiwi dan Sukadi dengan judul "Penerapan strategi pembelajaran E-Learning untuk Meningkatkan Hasil Belajar Siswa dalam Mata Pelajaran Pendidikan Kewarganegaraan pada Siswa Kelas X Tataniaga B di SMKN 1 Singaraja. Dalam penelitan tersebut diperoleh hasil pada siklus I rata-rata nilai hasil belajar siswa sebesar 74,31 dengan kategori baik dan ketuntasan klasikal 69\% yang tergolong belum tuntas. Meningkat pada siklus II menjadi 80,34 dengan ketuntasan klasikal 86\%. Dalam penelitian tersebut disimpulkan bahwa penerapan e-learning dapat meningkatkan hasil belajar siswa kelas X Tataniaga B di SMKN 1 Singaraja. Oleh karena itu, maka peneliti merasa sangat perlu diterapkan pembelajaran e-learning dengan media Schoology untuk meningkatkan motivasi dan hasil belajar siswa kelas X IPS 1 SMA Negeri 4 Jember.

Berdasarkan latar belakang diatas, maka rumusan masalah dalam penelitian ini yaitu: (1) Bagaimana penerapan E-Learning dengan media Schoology dalam meningkatkan motivasi dan hasil belajar siswa kelas X SOS 1 pada Kompetensi Dasar Konsep Badan Usaha dalam Perekonomian Indonesia SMAN 4 Jember semester genap tahun ajaran 2016/2017?. (2) Bagaimana peningkatan motivasi belajar siswa melalui penerapan E-Learning dengan media Schoology pada kelas X SOS 1 pada Kompetensi Dasar Konsep Badan Usaha dalam Perekonomian Indonesia SMAN 4 Jember semester genap tahun ajaran 2016/2017?. (3) Bagaimana peningkatan hasil belajar siswa melalui penerapan E-Learning dengan media Schoology pada kelas X SOS 1 pada Kompetensi Dasar Konsep Badan Usaha dalam Perokonomian Indonesia SMAN 4 Jember semester genap tahun ajaran 2016/2017? 


\section{METODE}

Penelitian ini merupakan penelitian tindakan kelas (PTK) yang dilaksanakan di SMAN 4 Jember sebanyak dua siklus. Subyek penelitian ini adalah seluruh siswa kelas X SOS 1 SMAN 4 Jember sebanyak 36 siswa. Teknik pengumpulan data dalam penelitian ini menggunakan metode observasi, wawancara, tes, dan dokumen. Metode analisis data menggunakan analisis data deskriptif kualitatif. Prosedur penelitian tindakan kelas ini setiap siklusnya terdiri atas empat kegiatan yaitu: (1)Perencanaan, (2) Pelaksanaan tindakan, (3) Pengamatan atau observasi, dan (4) Refleksi.

\section{HASIL DAN PEMBAHASAN}

Penelitian ini dilaksanakan sebanyak dua siklus, setiap siklus terdiri dari dua pertemuan. Pada siklus I guru sudah menerapkan pembelajaran e-learning dengan media Schoology dengan baik meskipun masih ada beberapa kendala yang disebabkan karena media Schoology merupakan media yang masih baru pertama kali digunakan di kelas X SOS 1 sehingga siswa masih kurang memahami cara penggunaan dari setiap fungsi menu dalam media Schoology. Kendala yang dihadapi pada siklus I dapat diperbaiki pada siklus II , sehingga pada siklus II pembelajaran e-learning dengan media Schoology berjalan dengan lancar dan sesuai perencanaan yang sudah dibuat pada RPP dan siswa sudah terbiasa menggunakan media Schoology. Media Schoology dalam penelitian ini tidak hanya digunakan didalam kelas, tetapi juga digunakan secara online (diluar kelas) rentang waktu pembelajaran siklus I dan siklus II. Kegiatan pembelajaran dengan media Schoology diluar kelas antara lain berdiskusi dengan temannya, menyampaikan pendapat dan mengajukan pertanyaan kapan saja, mengumpulkan tugas dan mengerjakan kuis. Sikap positif yang ditunjukkan siswa selama proses pembelajaran menunjukkan adanya peningkatan motivasi belajar siswa. Adapun skor motivasi belajar siswa pada siklus I dan siklus I terlihat dalam tabel 1 berikut :

Tabel 1. Rata-rata Motivasi Belajar Siswa Kelas X SOS 1 SMAN 4 Jember

\begin{tabular}{|c|l|c|c|c|c|}
\hline No. & \multicolumn{1}{|c|}{ Indikator Motivasi Belajar Siswa } & $\begin{array}{c}\text { Siklus } \\
\text { I }\end{array}$ & Kriteria & $\begin{array}{c}\text { Siklus } \\
\text { II }\end{array}$ & $\begin{array}{c}\text { Kriteri } \\
\text { a }\end{array}$ \\
\hline 1. & $\begin{array}{l}\text { Minat dan perhatian siswa terhadap } \\
\text { pelajaran }\end{array}$ & 3,1 & Tinggi & 3,7 & Tinggi \\
\hline 2. & $\begin{array}{l}\text { Semangat siswa untuk melakukan tugas- } \\
\text { tugas belajarnya }\end{array}$ & 2,4 & Sedang & 3,4 & Tinggi \\
\hline 3. & $\begin{array}{l}\text { Tanggung jawab dalam mengerjakan } \\
\text { tugas-tugas belajarnya }\end{array}$ & 3 & Sedang & 3,5 & Tinggi \\
\hline 4. & $\begin{array}{l}\text { Reaksi yang ditunjukkan siswa terhadap } \\
\text { stimulus yang diberikan guru }\end{array}$ & 2,1 & Sedang & 3,1 & Tinggi \\
\hline 5. & $\begin{array}{l}\text { Rasa senang dan puas mengerjakan } \\
\text { tugas yang diberikan oleh guru }\end{array}$ & 3 & Sedang & 3,6 & Tinggi \\
\hline & Jumlah skor rata-rata & 2,7 & Sedang & 3,5 & Tinggi \\
\hline
\end{tabular}

Sumber:Data primer yang diolah 2017

Tabel 1 diatas menunjukkan bahwa skor rata-rata motivasi belajar siswa mengalami peningkatan. Pada siklus I skor rata-rata motivasi belajar siswa sebesar 2,7 dengan kriteria sedang, meningkat pada siklus II menjadi 3,5 dengan kriteria tinggi. Indikator minat dan perhatian siswa terhadap pelajaran dan tanggung jawab siswa dalam mengerjakan tugas-tugas belajarnya baik pada siklus I maupun siklus II sudah berada pada kriteria tinggi. Sedangkan indikator semangat siswa untuk melakukan tugas-tugas belajarnya, reaksi yang ditunjukkan siswa terhadap stimulus yang diberikan 
guru, dan rasa senang dan puas mengerjakan tugas yang diberikan guru berada pada kriteria sedang pada siklus I dan meningkat pada siklus II menjadi tinggi. Peningkatan motivasi belajar siswa diatas, dapat dilihat pada gambar diagram berikut.

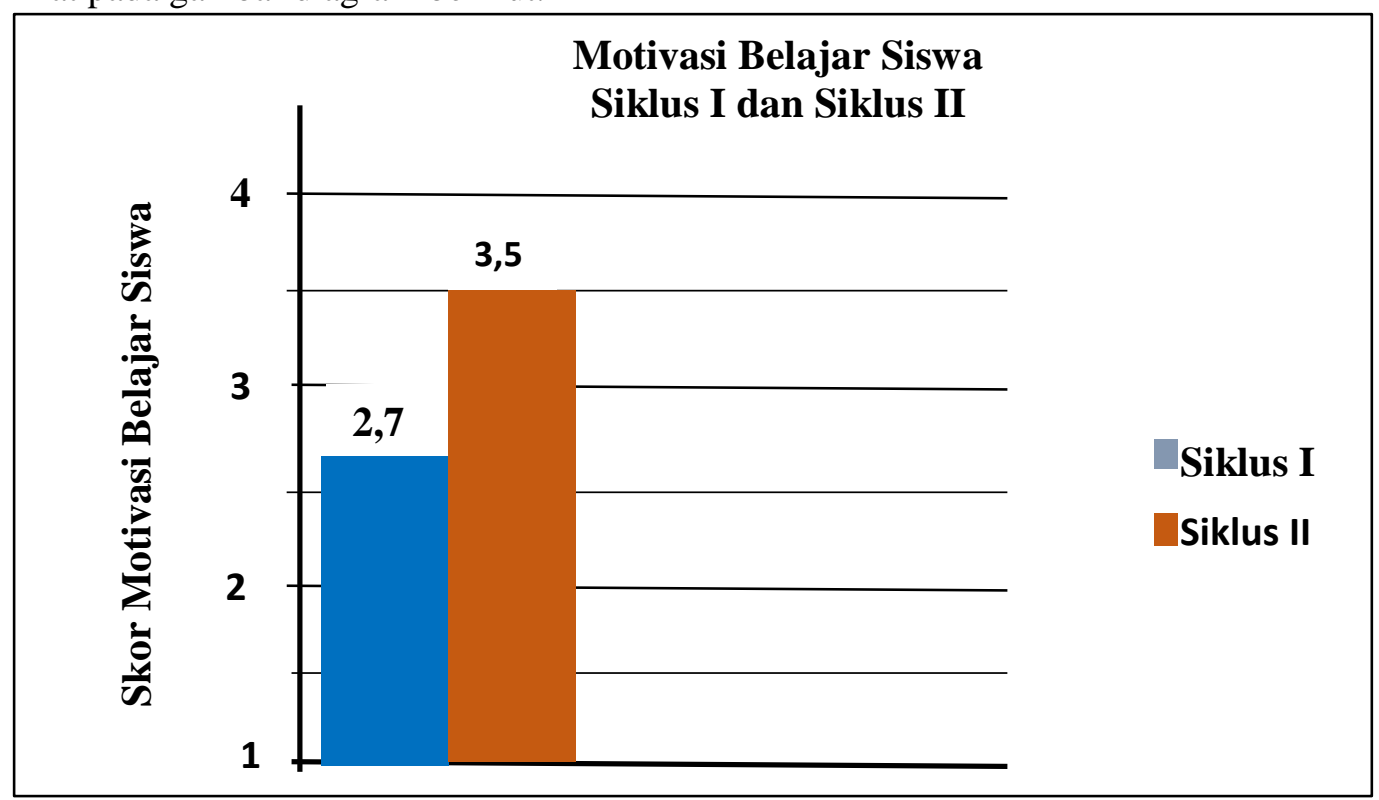

Gambar 1. Diagram peningkatan motivasi belajar siswa Siklus I dan Siklus II Sumber: Data primer yang diolah 2017

Gambar diatas menunjukkan bahwa adanya peningkatan skor rata-rata motivasi belajar siswa dari siklus I sampai siklus II. Peningkatan skor rata-rata motivasi belajar pada siklus II menunjukkan skor 3,5 dengan kriteria tinggi. Hal tersebut ditunjukkan dengan siswa memperhatikan penjelasan guru dan semangat mengikuti pembelajaran dengan media Schoology dengan baik, aktif bertanya dan menjawab pertanyaan yang diberikan baik secara langsung dikelasa maupun melalui media Schoology, dan lebih bertanggung jawab terhadap tugas-tugas belajarnya karena media Schoology memberikan kemudahan bagi siswa untuk mengerjakan dan mengumpulkan tugas yang diberikan guru.

Peningkatan motivasi belajar diatas, ternyata juga diikuti dengan peningkatan hasil belajar siswa. Setelah dilakukan tes atau ulangan harian yang diadakan tiap akhir siklus, maka dapat dilihat rata-rata hasil belajar siswa seperti yang tampak pada tabel berikut.

Tabel 2 Rekapitulasi Hasil Belajar Siswa siklus I dan siklus II

\begin{tabular}{|c|c|c|c|c|c|c|c|c|c|c|c|}
\hline \multirow{2}{*}{$\begin{array}{c}\text { Jum. } \\
\text { Sisw } \\
\text { a }\end{array}$} & \multicolumn{2}{|c|}{$\begin{array}{c}\text { Nilai } \\
\text { Rata-rata }\end{array}$} & \multirow[t]{2}{*}{$\begin{array}{c}\text { Pening } \\
\text { katan }\end{array}$} & \multicolumn{2}{|c|}{$\begin{array}{l}\text { Jum. } \\
\text { Siswa } \\
\text { Tuntas }\end{array}$} & \multicolumn{2}{|c|}{$\begin{array}{c}\text { Jumlah } \\
\text { Siswa } \\
\text { Tidak } \\
\text { Tuntas }\end{array}$} & \multicolumn{2}{|c|}{$\begin{array}{c}\text { Ketuntasan } \\
\text { Klasikal }\end{array}$} & \multirow[t]{2}{*}{$\begin{array}{l}\text { Pening } \\
\text { katan }\end{array}$} & \multirow[t]{2}{*}{$\begin{array}{c}\text { Ketera } \\
\text { ngan }\end{array}$} \\
\hline & $\begin{array}{c}\text { Sik. } \\
\text { I }\end{array}$ & $\begin{array}{c}\text { Sik. } \\
\text { II }\end{array}$ & & $\begin{array}{c}\text { Sik. } \\
\text { I }\end{array}$ & $\begin{array}{c}\text { Sik. } \\
\text { II }\end{array}$ & Sik.I & $\begin{array}{c}\text { Sik. } \\
\text { II }\end{array}$ & Sik.I & Sik.II & & \\
\hline 36 & $\begin{array}{l}78, \\
19\end{array}$ & $\begin{array}{c}86, \\
19\end{array}$ & 8 & 27 & 30 & 9 & 6 & $75 \%$ & $\begin{array}{c}83,33 \\
\%\end{array}$ & $8.33 \%$ & Tuntas \\
\hline
\end{tabular}

Sumber: Data primer yang diolah 2017

Tabel 2 diatas menunjukkan bahwa hasil belajar dari siklus I sampai siklus II mengalami peningkatan. Pada siklus I nilai rata-rata siswa sebesar 78,19 dengan ketuntasan klasikal 75\%, pada 
siklus II nilai rata-ratanya naik menjadi 86,19 dengan ketuntasan klasikal 83,33\%. Tabel peningkatan hasil belajar diatas dapat digambarkan dalam diagram berikut.

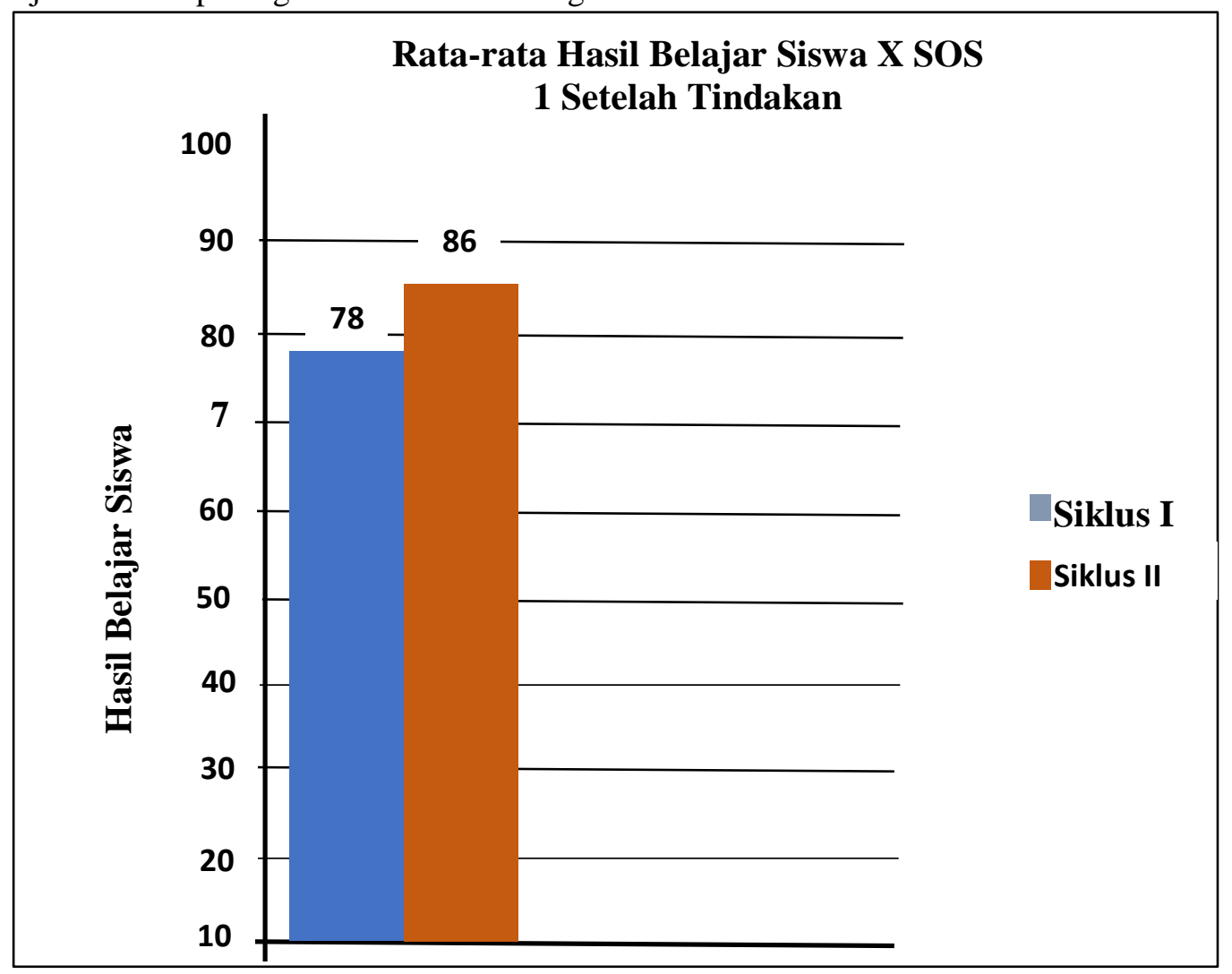

Gambar 2. Diagram Hasil Belajar Siswa Siklus I dan Siklus II Sumber : Data vang diolah 2017

Berdasarkan gambar diagram analisis hasil belajar siswa diatas, dapat diketahui peningkatan hasil belajar siswa setelah dilakukan tindakan perbaikan dengan menerapkan e-learning dengan media Schoology pada kompetensi dasar mendeskripsikan konsep badan usaha dalam perekonomian Indonesia. Nilai rata-rata hasil belajar pada siklus I sebesar 78,19 dengan ketuntasan klasikal 75\% meningkat menjadi 86,19 dengan ketuntasan klasikal sebesar 83,33\% pada siklus II. Peningkatan hasil belajar tersebut menunjukkan bahwa target penelitian telah tercapai yaitu siswa yang mendapatkan nilai lebih dari KKM yang ditentukan sekolah yaitu $\geq 78$ lebih dari $75 \%$ dari seluruh siswa kelas X SOS 1 .

Pembahasan

Berdasarkan penelitian yang telah dilaksanakan di kelas X SOS 1 SMAN 4 Jember bahwa pelaksanaan penerapan E-Learning dengan media Schoology berjalan lancar dan sesuai rencana yang sudah disusun pada tahap perencanaan. Hasil penelitian menunjukkan bahwa penerapan E-Learning dengan media Schoology dapat meningkatkan motivasi dan hasil belajar siswa pada mata pelajaran ekonomi kompetensi dasar mendeskripsikan konsep badan usaha dalam perekonomian Indonesia kelas X SOS 1 SMAN 4 Jember tahun ajaran 2016/2017.

Hasil penelitian menunjukkan bahwa pada siklus I skor motivasi belajar siswa pada kriteria sedang dan pada siklus meningkat menjadi tinggi. Peningkatan motivasi belajar siswa dapat dilihat pada saat proses pembelajaran dengan menerapkan E-Learning dengan media Schoology, siswa sangat antusias mengikuti proses pembelajaran dengan mendengarkan dan memperhatikan video yang 
diberikan guru melalui media Schoology, siswa segera mengerjakan tugas yang diberikan guru melalui media Schoology, dan siswa juga sudah tepat waktu mengumpulkan tugas melalui media Schoology. Selain itu, siswa juga menunjukkan respon positif terhadap stimulus yang diberikan guru, seperti siswa aktif bertanya ketika guru memberikan kesempatan bertanya dan siswa juga saling berebut kesempatan menjawab ketika guru memberikan pertanyaan-pertanyaan secara langsung. Siswa juga aktif ada yang bertanya kepada guru ketika diluar pertemuan atau diluar jam pelajaran mengenai tugas yang tidak dipahaminya dan aktif menyampaikan pendapatnya melalui media Schoology.

Peningkatan motivasi belajar siswa tersebut sesuai dengan yang diungkapkan Siahaan (dalam Darmawan, 2014:37) bahwa dengan pembelajaran E-Learning siswa akan memiliki motivasi belajar mandiri yang tinggi dan memiliki komitmen untuk belajar bersungguh-sungguh karena tanggung jawab belajar sepenuhnya berada pada diri siswa itu sendiri. Peningkatan motivasi belajar siswa juga diakui oleh guru mata pelajaran ekonomi kelas X SOS 1 SMAN 4 Jember yang menyatakan:

“....motivasi belajar siswa tinggi, terlihat dari siswa aktif bertanya dan menjawab pertanyaan yang saya berikan secara langsung maupun melalui media Schoology apalagi siswa lebih bebas berpendapat melalui Schoology dan siswa juga tepat waktu dalam mengumpulkan tugas melalui Schoology karena mereka hanya mengumpulkan filenya saja tidak perlu print, meskipun beberapa siswa masih ada yang telat, tetapi ratarata motivasi belajarnya sudah lebih bagus.". (Ibu YSB, 43 Tahun).

Pernyataan guru ekonomi diatas didukung oleh pendapatnya Warsita (2011:51) bahwa dengan e-learning siswa memiliki keleluasaan atau kebebasan untuk mengungkapkan pendapatnya atau mengajukan pertanyaan karena tidak ada siswa lain yang secara fisik mengamatinya, sehingga siswa yang kurang percaya diri tidak lagi merasa khawatir dikritik atau diremehkan temannya. Peningkatan motivasi belajar siswa juga dirasakan oleh siswa berdasarkan hasil wawancara kepada siswa yang memiliki hasil belajar tertinggi, yaitu:

“...iya termotivasi bu, menyenangkan karena belajarnya terkoneksi dengan internet dan dalam media schoology saya bisa belajar materi dengan bentuk gambar dan video yang menarik serta e-book yang bisa dipelajari kapan-kapan, jadi saya lebih mudah paham materi, dan ulangannya secara online juga lebih seru". (Siswa KNM, 16 Tahun).

Pernyataan siswa diatas sesuai dengan pendapat Aminoto (2014) mengemukakan bahwa Schoology didukung oleh berbagai bentuk media seperti video, audio dan gambar yang dapat menarik minat siswa, dan minat merupakan salah satu indikator dalam motivasi belajar. Selain itu, juga sesuai dengan pendapat Rusman (2014:351) bahwa salah satu kelebihan e-learning adalah siswa dapat belajar atau me-review bahan ajar atau materi setiap saat dan dimana saja ketika diperlukan, karena bahan ajar atau materi tersimpan dalam media $e$-learning yang digunakan, dimana dalam penelitian ini media yang digunakan adalah media Schoology.

Peningkatan hasil belajar diatas, juga diikuti oleh peningkatan hasil belajar siswa. Siklus I nilai rata-rata siswa mencapai 78,19 dengan ketuntasan klasikal 75\% meningkat pada siklus II menjadi 86,19 dengan persentase ketuntasan klasikal sebesar $83,33 \%$. Sehingga dapat dikatakan hasil tes ulangan harian dinyatakan tuntas dan telah mencapai target penelitian. Peningkatan hasil belajar diatas membuktikan teori Sanaky (2013:211) bahwa penerapan e-learning dapat menigkatkan hasil belajar siswa dengan penggunaan waktu dan biaya yang relatif kecil.

Berdasarkan hasil penelitian tindakan ini menunjukkan bahwa hipotesis tindakan terbukti menjawab tujuan penelitian yaitu penerapan E-Learning dengan media Schoology pada kompetensi dasar mendeskripsikan konsep badan usaha dalam perekonomian Indonesia kelas X SOS 1 SMAN 4 Jember tahun ajaran 2016/2017 dapat meningkatkan motivasi dan hasil belajar siswa. 


\section{PENUTUP}

Berdasarkan hasil penelitian dan pembahasan, dapat disimpulkan bahwa penerapan E-Learning dengan media Schoology dapat meningkatkan motivasi dan hasil belajar siswa pada kompetensi dasar mendeskripsikan konsep badan usaha dalam perekonomian Indonesia kelas X SOS 1 SMAN 4 Jember tahun ajaran 2016/2017. Peningkatan motivasi belajar siswa dapat dilihat dari skor rata-rata motivasi belajar pada siklus I sebesar 2,7 dengan kriteria sedang, meningkat pada siklus II 3,5 dengan kriteria tinggi. Peningkatan hasil belajar siswa dapat dilihat dari rata-rata ulangan harian siswa sebelum tindakan yaitu 69,5 dengan ketuntasan klasikal sebesar 52,77\% meningkat menjadi 78,19 dengan ketuntasan klasikal 75\% pada siklus I. Kemudian pada siklus II meningkat lagi menjadi 86,19 dengan ketuntasan klasikal 83,33\%, jadi hampir seluruh siswa tuntas

Berdasarkan hasil penelitian dapat diajukan saran bahwa penerapan e-learning dengan media Schoology dapat dijadikan alternatif bagi guru dalam malakukan pembelajaran baik dikelas maupun diluar kelas, karena Schoology dapat digunakan dimanapun dan kapanpun atau tidak ada batasan waktu penggunaannya, maka sebaiknya guru membiasakan menggunakan media Schoology ini terutama ketika guru tidak dapat mengisi pelajaran dikelas, sehingga siswa tetap dapat melaksanakan pembelajaran meskipun tidak ada gurunya.

\section{DAFTAR PUSTAKA}

Aminoto dan Pathoni, 2014. Penerapan Media E-Learning Berbasis Schoology untuk Meningkatkan Aktivitas dan Hasil Belajar Materi Usaha dan Energi di Kelas XI SMAN 10 Kota Jambi. Jurnal Sainmatika Vol 8 No 12014 ISSN 1979-0910. Jambi: Universitas Jambi.

Darmawan, Deni. 2014. Pengembangan E-Learning Teori dan Desain. Bandung. PT Remaja Rosdakarya.

Rusman. 2014. Model-Model Pembelejaran (Mengembangkan Profesionalitas Guru). Jakarta: PT Rajagrafindo Persada.

Sanaky, Hujair. 2013. Media Pembelajaran Interaktif-Inovatif. Yogyakarta: Kaukaba Dipantara

Warsita, Bambang. 2011. Pendidikan Jarak Jauh. Bandung: PT Remaja Rosdakarya. 